\title{
PURIFICATION AND CHARACTERIZATION OF SOY COTYLEDON $\beta$-GLUCOSIDASE
}

\author{
R.F. SANTOS ${ }^{1}$, C.F. OLIVEIRA ${ }^{1}$, G.S. VARÉA ${ }^{1}$, M.L.C. ORRADI DA SILVA ${ }^{2}$, E.I. IDA ${ }^{3}$, J.M.G. MANDARINO ${ }^{4}$, \\ M.C. CARRÃO-PANIZZI ${ }^{4}$ and M.L.L. RIBEIRO ${ }^{1,5}$ \\ 1Biochemistry and Biotechnology Department, Universidade Estadual de Londrina. Caixa Postal 6001, CEP 86.051-990, Londrina, PR, Brazil \\ ${ }^{2}$ Carbohydrate Biochemistry Laboratory, Physics, Chemistry and Biology Department, Science and Technology College, UNESP - Presidente Prudente, \\ SP, Brazil \\ ${ }^{3}$ Food Technology and Science Department, Universidade Estadual de Londrina. Caixa Postal 6001, Londrina, PR, Brazil \\ ${ }^{4}$ Embrapa (Brazilian Enterprise for Agricultural Research)-Nacional Soy Research Center (CNPSo), Londrina, PR, Brazil
}

${ }^{5}$ Corresponding author. TEL:

55-43-3371-4270; FAX: 55-43-3371-4270;

EMAIL: maraluciaribeiro@uel.br

Accepted for Publication August 18, 2011

doi:10.1111/j.1745-4514.2011.00632.x

\begin{abstract}
$\beta$-Glucosidase $\mathrm{F}_{42}$ of soy cotyledons was purified by ammonium sulfate fractionation, ion-exchange chromatography (CM-Sephadex-C-50, Sigma, St. Louis, MO) and gel filtration (Sephadex G-100, Sigma). The enzyme was purified 111.8-fold relative to its concentration in the crude extract. It had an apparent molecular mass of $53 \mathrm{kDa}$ in gel filtration experiments and produced a $33-\mathrm{kDa}$ band in sodium dodecyl sulfate-polyacrylamide gel electrophoresis, suggesting that it is dimeric. The purified $\beta$-glucosidase $\mathrm{F}_{42}$ was characterized as a glycoprotein after the identification of fucose, galactosamine and glucosamine by high-pressure anion-exchange chromatography-pulsed amperometric detector. Its highest activity was observed at $\mathrm{pH} 5.0$ and $45 \mathrm{C}$, and it was stable for up to 4 days at $25 \mathrm{C}$. The $K_{\mathrm{m}}$ of the enzyme was $0.12 \mathrm{mM} p$-nitrophenyl- $\beta$-D-glucopyranoside. $\beta$-Glucosidase $\mathrm{F}_{42}$ showed specificity for different substrates, and its activity was inhibited by $1 \mathrm{mM} \mathrm{HgCl}_{2}, 10 \mathrm{mM}$ glucono- $\delta$-lactone or $150 \mathrm{mM}$ glucose and increased by $10 \mathrm{mM} \mathrm{MnCl}_{2}$.
\end{abstract}

\section{PRACTICAL APPLICATIONS}

$\beta$-Glucosidase is an enzyme that hydrolyzes $\beta$-glucosidic bonds to liberate glucose and hydrolyzes isoflavones to release aglycones. Soy aglycones have been broadly investigated because of their biological activity in the prevention and treatment of some chronic diseases. Soy $\beta$-glucosidase can be used in the food industry to alter soy isoflavones for the production of functional foods that are rich in aglycone isoflavones. Therefore, it was an established method of purification of the enzyme that has great biotechnological potential.

\section{INTRODUCTION}

$\beta$-Glucosidase ( $\beta$-D-glucoside glucohydrolase, EC. 3.2.1.21) catalyzes the hydrolysis of the nonreducing terminals of compounds containing $\beta$-D-glucose residues, with glucose released as a result. This enzyme is produced by fungi, bacteria and many vegetables. In vegetables, it takes part in numerous functions, such as the hydrolysis of conjugated gibberellins, the conversion of stored cytokinins to active forms, stress metabolism and resistance to some phytopathogens (Esen 1992; Faure 2002; Morant et al. 2008).
The consumption of soy has increased in the last few decades because of the importance of its nutritional and biological properties. The nutritional properties of soy are its high protein content and high-quality oil. The biological properties of soy include the presence of isoflavones that have phytoestrogenic (Liu et al.2010), antioxidant (Ma et al.2010) and antitumor activities (Lai and Yen 2002). However, in humans, the bioavailability of soy isoflavones depends on their metabolism, which can differ depending on ethnic groups, dietary habits and the presence of appropriate intestinal microflora. These factors promote changes in the amount 
and activity of the intestinal $\beta$-glucosidases that hydrolyze the $\beta$-glucosides in aglycones (Ismail and Hayes 2005). The $\beta$-glucosides show less estrogenic activity than aglycones with greater absorption properties (Izumi et al. 2000; Brouns 2002).

Isolation and purification of $\beta$-glucosidase has great potential in biotechnological applications in the food industry (Santosh et al. 1999; Bhatia et al. 2002; Chiou et al. 2010). $\beta$-Glucosides can be converted to soy aglycones by crude $\beta$-glucosidases from fungal or bacterial origins (Matsuda et al. 1992; Aguiar and Park 2004; Otieno and Shah 2007; Chun et al. 2008) or by $\beta$-glucosidases originating from the grain itself (Araújo et al. 1997). However, the purification and characterization of soy $\beta$-glucosidases is relatively unexplored, with investigations previously conducted only in whole flour and in the root of germinate soy, both of which yielded partially purified enzyme (Matsuura and Obata 1993; Hsieh and Graham 2001; Suzuki et al. 2006).

In this study, $\beta$-glucosidase $\mathrm{F}_{42}$ of soy cotyledons was purified by fractionation with ammonium sulfate, ion-exchange chromatography and gel filtration. Its biochemical properties were then characterized.

\section{MATERIALS AND METHODS}

\section{Raw Material}

The soy cultivar BRS 213 (Glycine Max [L.] Merrill), 2002/ 2003 harvest, developed at the Embrapa Soy Experimental Farm in Londrina, PR, Brazil, was used.

\section{Extraction, Fractionation and Purification of $\beta$-Glucosidase}

Extraction. The conditions for $\beta$-glucosidase extraction were as described by Matsuura and Obata (1993), with $60 \mathrm{~g}$ of soy cotyledon flour and $100 \mathrm{mM}$ sodium phosphate buffer, $\mathrm{pH} 6.6$, in a 1:10 proportion $(\mathrm{w} / \mathrm{v})$ slowly agitated for $1 \mathrm{~h}$ at $4 \mathrm{C}$ and then centrifuged at $4,000 \times \mathrm{g}$ at $4 \mathrm{C}$ for $15 \mathrm{~min}$. The supernatant was acidified with $0.1 \mathrm{M} \mathrm{HCl}$ to $\mathrm{pH}$ 5.0, and the samples were centrifuged again under the same conditions. The supernatant obtained following this step was the crude extract used for fractionation and purification.

Fractionation. The crude extract was first precipitated by ammonium sulfate at $40 \%$ saturation. The sample was then placed at $4 \mathrm{C}$ until precipitation was complete. The precipitated protein $\left(\mathrm{P}_{0-40}\right)$ was collected after centrifugation at $4,000 \times \mathrm{g}$ for $15 \mathrm{~min}$ at $4 \mathrm{C}$, and ammonium sulfate was added to the supernatant until $85 \%$ saturation was achieved. The second precipitate $\left(\mathrm{P}_{40-85}\right)$ was then obtained using the above conditions. The precipitates were resuspended in a $50 \mathrm{mM}$ citrate phosphate buffer, $\mathrm{pH}$ 5.0. The supernatants $\left(\mathrm{S}_{0-40}\right.$ and $\left.\mathrm{S}_{40-85}\right)$ and precipitates $\left(\mathrm{P}_{0-40}\right.$ and $\left.\mathrm{P}_{40-85}\right)$ were dialyzed with the same buffer for $14 \mathrm{~h}$ at $4 \mathrm{C}$. The activity of $\beta$-glucosidase and the soluble protein content were then determined. The $\mathrm{P}_{40-85}$ fraction with the highest $\beta$-glucosidase activity was concentrated using an ultrafiltration cell (Amicon, model 8400; Millipore, Billerica, MA) with a $1-\mathrm{kDa}$ molecular exclusion membrane (Regenerated cellulose, Millipore).

Purification. The concentrated $\mathrm{P}_{40-85}$ fraction was applied to a CM-Sephadex C-50 ion-exchange column $(2.5 \mathrm{~cm} \times$ $55 \mathrm{~cm}$ ). Ion-exchange chromatography starts with conditioning $50 \mathrm{mM}$ citrate phosphate buffer, $\mathrm{pH}$ 5.0, without $\mathrm{NaCl}$ and the protein eluted is nonretained protein $\left(\mathrm{F}_{1}\right)$. Elution of retained protein $\left(\mathrm{F}_{2}, \mathrm{~F}_{3}\right.$ and $\left.\mathrm{F}_{4}\right)$ is carried out by means of increasing the buffer ionic strength with $\mathrm{NaCl}$ $(0-1 \mathrm{M})$. The elution flow was $27 \mathrm{~mL} / \mathrm{h}$, and $3.5 \mathrm{~mL}$ of fractions was collected in a test tube. Absorbance readings at $280 \mathrm{~nm}$ were measured for the eluted fractions and $\beta$-glucosidase activity was determined. Fraction $\mathrm{F}_{4}$, which had the highest $\beta$-glucosidase-specific activity, was concentrated by membrane ultrafiltration at $1 \mathrm{kDa}$, dialyzed against a $100 \mathrm{mM}$ citrate phosphate buffer at $\mathrm{pH} 5.0$ and applied to a Sephadex G-100 gel filtration column that was equilibrated with a $100 \mathrm{mM}$ citrate phosphate buffer at $\mathrm{pH}$ 5.0. The elution flow was $17 \mathrm{~mL} / \mathrm{h}$, and $2.3 \mathrm{~mL}$ of fractions was collected in a test tube. Absorbance readings at $280 \mathrm{~nm}$ were performed on the eluted fractions and $\beta$-glucosidase activity was determined. In this assay, three protein fractions were separated $\left(\mathrm{F}_{41}, \mathrm{~F}_{42}\right.$ and $\left.\mathrm{F}_{43}\right)$. The $\beta$-glucosidase $F_{42}$ fraction showed the highest specific activity and was thus used for biochemical characterization.

$\beta$-Glucosidase Activity. $\beta$-Glucosidase activity in the different extraction and purification fractions was determined using the $p$-nitrophenyl- $\beta$-D-glucopyranoside ( $p$-NPG) substrate according to the procedures described by Matsuura and Obata (1993). The standard curve of $p$-nitrophenol $(0.04-0.32 \mu \mathrm{mol})$ was prepared. A $\beta$-glucosidase activity unit (U) was defined as the amount of enzyme needed to liberate $1 \mu \mathrm{mol}$ of $p$-nitrophenol/min under assay conditions.

The soluble protein content was quantified using the method described by Lowry et al. (1951) with a bovine serum albumin standard solution, and the specific $\beta$-glucosidase activity of each fraction was determined as the relationship between the enzymatic activity and the protein content, and this value was expressed as $\mathrm{U} / \mathrm{mg}$. 


\section{Biochemical Characterization of Purified $\beta$-Glucosidase $\mathbf{F}_{42}$}

Homogeneity Assay by Native-Polyacrylamide Gel Electrophoresis (PAGE). Native-PAGE (10\% w/v) analysis of fractions ( $\mathrm{EB}, \mathrm{P}_{0-40}, \mathrm{P}_{40-85}, \mathrm{~F}_{4}$ and $\mathrm{F}_{42}$ ) was performed according to the method of Davis (1964) and gels were stained with silver nitrate (Nielsen and Brown 1984).

Molecular Mass Determination by Gel Filtration and Sodium Dodecyl Sulfate-Polyacrylamide Gel Electrophoresis (SDS-PAGE). The molecular mass of native purified $\beta$-glucosidase $\mathrm{F}_{42}$ was estimated using gel filtration in a Sephadex G-100 column $(2.3 \mathrm{~cm} \times 100 \mathrm{~cm})$ that was equilibrated with $100 \mathrm{mM}$ citrate phosphate buffer at $\mathrm{pH}$ 5.0. A $1 \mathrm{~mL} / \mathrm{h}$ flow was used, $2.3 \mathrm{~mL}$ of fractions was collected in tubes, and absorbance readings were performed at $280 \mathrm{~nm}$. The protein standards were $\beta$-amylase $(200 \mathrm{kDa})$, alcohol dehydrogenase $(150 \mathrm{kDa})$, bovine serum albumin $(66 \mathrm{kDa})$, carbonic anhydrase $(29 \mathrm{kDa})$ and cytochrome $c$ $(12.4 \mathrm{kDa})$. Blue dextran $(2,000 \mathrm{kDa})$ was used to determine the void volume. The molecular mass was graphically estimated as the $\log$ of the standard molecular mass in the ordinate versus $K_{\mathrm{av}}$ in the abscissa. The $V_{\mathrm{e}}$ value of each sample was the sum of the collected fraction volumes from the application of the sample until the fraction where the highest absorbance reading was recorded.

The molecular mass of the purified $\beta$-glycosidase $\mathrm{F}_{42}$ was also estimated using SDS-PAGE with $\beta$-mercaptoethanol according to the method described by Laemmli (1970). A $4 \%$ stacking gel and a $10 \%$ separation gel buffered with $1.5 \mathrm{M}$ Tris-HCl with SDS at $\mathrm{pH} 8.9$ was used. SDS-PAGE was run in a vertical system at $100 \mathrm{mV}$ and 4C. Samples were prepared in a 1:1 (v/v) sample buffer and boiled for 10 min before loading onto the gel. The molecular mass was estimated using the relationship between the $\log$ of the molecular weights and relative mobilities of $6-$ to $180-\mathrm{kDa}$ standards (BenchMark Pre-stained Protein Ladder; Invitrogen, Carlsbad, CA). The protein bands were stained with silver nitrate (Nielsen and Brown 1984).

Identification of Monosaccharides in the Purified $\beta$ Glucosidase $F_{42}$. The purified $\beta$-glucosidase $\mathrm{F}_{42}$ was evaluated for the presence of neutral and acidic monosaccharides using high-pressure anion-exchange chromatography (HPAEC) in a Dionex DX 500 system with a pulsed amperometric detector (PAD) and a CarboPac PA10 analytical column $(4 \times 250 \mathrm{~mm})$ equipped with an Amino Trap (Dionex, Sunnyvale, CA) guard column. The elution conditions were $16 \mathrm{mM} \mathrm{NaOH}$ in deionized water (eluent 1 ) and $0.2 \mathrm{M} \mathrm{NaOH}$ (eluent 2) with a $1.0 \mathrm{~mL} / \mathrm{min}$ flow rate (Elifio et al. 2000). The column was regenerated after 20 min with $100 \%$ eluent 2, followed by $15 \mathrm{~min}$ of $16 \mathrm{mM} \mathrm{NaOH}$ before addition of a new sample. Purified $\beta$-glucosidase $\mathrm{F}_{42}$ samples containing $2 \%$ carbohydrates were previously subjected to acid hydrolysis in a heater (Digi-Block, Laboratory Devices Inc., Placerville, CA) at $120 \mathrm{C}$ for $2 \mathrm{~h}$ using trifluoroacetic acid (Merck KGaA, Darmstadt, Germany) and $4 \mathrm{M} \mathrm{HCl}$ to release the neutral and acidic monosaccharides (Corradi da Silva et al. 2005). The hydrolyzed sample was then completely evaporated using a vacuum centrifuge (HETO mod DNA Plus, Jouan Nordic, Allerød, Denmark), followed by three cycles of water addition and complete evaporation.

Effects of Temperature, $\mathrm{pH}$ and $p$-NPG Concentration on $\beta$-Glucosidase $F_{42}$ Activity. The optimal temperature for purified $\beta$-glucosidase $\mathrm{F}_{42}$ was assayed at different temperatures from 4 to $70 \mathrm{C}$ for $30 \mathrm{~min}$ at $\mathrm{pH}$ 5.0. The optimal $\mathrm{pH}$ was determined under different $\mathrm{pH}$ conditions (3.0-8.0) at 45C. Activities are expressed as a percentage of $\beta$-glucosidase activity as a function of temperature or $\mathrm{pH}$.

The effect of $p$-NPG concentrations $(0.1-20 \mathrm{mM})$ on purified $\beta$-glucosidase $\mathrm{F}_{42}$ activity was determined at $\mathrm{pH} 5.0$, $30 \mathrm{~min}$ incubation at $45 \mathrm{C}$. The results were expressed as $\mathrm{U} / \mathrm{mg}$ protein. The Michaelis constant $\left(K_{\mathrm{m}}\right)$ was estimated using the Lineweaver-Burk plot method.

Enzyme Thermal Stability. The thermal stability of the purified $\beta$-glucosidase $\mathrm{F}_{42}$ was evaluated by incubating the enzyme at different temperatures $(25,45,50,60$ and $70 \mathrm{C})$, after incubating for different intervals (5 min, 10 days) and after four successive freeze-thaw cycles. The $\beta$-glucosidase activity was measured by assaying the remaining activity at $45 \mathrm{C}$ for $30 \mathrm{~min}$.

Specificity of Purified $\beta$-Glucosidase $F_{42}$ Toward Different Substrates. The specificity of $\beta$-glucosidase $F_{42}$ was investigated under optimal conditions, $\mathrm{pH} 5.0$ and a 30 -min incubation period at $45 \mathrm{C}$ using various substrates at a concentration of $1 \mathrm{mM}$. The specificity for daidzin and genistin was assessed using the methods described by Matsuura and Obata (1993) with $400 \mu \mathrm{L}$ of $1 \mathrm{mM}$ substrate and $100 \mu \mathrm{L}$ of sample, followed by $2 \mathrm{~mL}$ of methanol to stop the reaction. The quantitative analysis of liberated daidzein and genistein aglycones was conducted using high-pressure liquid chromatography (HPLC) according to the methods described by Berhow (2002). One unit of enzyme (U) was defined as the amount of enzyme necessary to liberate $1 \mu \mathrm{mol}$ aglycone/min under assay conditions.

The specificity of $\beta$-glucosidase $\mathrm{F}_{42}$ activity was also investigated for substrates derived from $\beta$-D-glucosides: salicin, cellobiose, gentiobiose, amygdalin, esculin and methyl- $\beta$-Dglucopyranoside. $\beta$-Glucosidase $\mathrm{F}_{42}$ activity was determined 
using the glucose oxidase method with an automated system (Selectra 1, Vitalab/Merck). In this procedure, the liberated glucose was quantified by spectrophotometry at $420 \mathrm{~nm}$. One unit of $\beta$-glucosidase $(U)$ was defined as the amount of enzyme necessary to liberate $1 \mu \mathrm{mol}$ glucose/min under assay conditions. The specificity of enzyme for substrates derived from $p$ - and $o$-nitrophenol was compared with the $p$-NPG substrate (100\% activity).

\section{Effects of Metallic lons and Organic Compounds on the Activity of $\beta$-Glucosidase $\mathbf{F}_{42}$}

The effects of metallic ions and organic compounds on $\beta$-glucosidase $\mathrm{F}_{42}$ activity were determined at $\mathrm{pH} 5.0$ and 30C with 30 -min incubation. The $\beta$-glucosidase $\mathrm{F}_{42}$ was incubated in $100 \mathrm{mM}$ citrate phosphate buffer with the addition of the metallic ions $\mathrm{HgCl}_{2}, \mathrm{AgNO}_{3}, \mathrm{MnCl}_{2}, \mathrm{CaCl}_{2}, \mathrm{CoCl}_{2}, \mathrm{ZnSO}_{4}$ and $\mathrm{CuSO}_{4}$ and the organic compounds glucone- $\delta$-lactone, phenylmethylsulfonyl fluoride (PMSF) and ethylenediaminetetraacetic acid (EDTA) salts at 1 and $10 \mathrm{mM}$ concentrations. The results are expressed as the percentage of $\beta$-glucosidase activity compared with the control.

The effect of concentration of glucose $(1,10,50,100$ and $150 \mathrm{mM})$ on the activity of $\beta$-glucosidase $F_{42}$ was tested in $p$-NPG ( 1 and $2 \mathrm{mM})$. The inhibition constant $\left(K_{\mathrm{i}}\right)$ was determined using the Dixon (1953) representation.

\section{RESULTS AND DISCUSSION}

\section{Soy Cotyledon $\beta$-Glucosidase $F_{42}$ Purification}

Purification of soy cotyledon $\beta$-glucosidase $F_{42}$ activity is summarized in Table 1. Sixty grams of soy cotyledons in $100 \mathrm{mM}$ sodium phosphate buffer, $\mathrm{pH}$ 6.6, was acidified with
$0.1 \mathrm{M} \mathrm{HCl}$ to $\mathrm{pH}$ 5.0. From this, it was possible to obtain a crude extract with $4.81 \mathrm{U}$ and 2,782.0 $\mathrm{mg}$ of soluble protein. The crude extract was fractionated by ammonium sulfate precipitation, and most activity was detected in $40-85 \%$ saturation $\left(\mathrm{P}_{40-85}\right)$.

The $\mathrm{P}_{40-85}$ fraction loaded onto an ion-exchange chromatography CM-Sephadex C-50 was eluted with a $50 \mathrm{mM}$ citrate phosphate buffer to separate a protein fraction with $\beta$-glucosidase activity that was called fraction $\mathrm{F}_{1}$. This fraction contained $1.8 \%$ of the $\beta$-glucosidase activity and $2 \%$ of the protein (Table 1 and Fig. 1), which may be a new alternative source of $\beta$-glucosidase that needs further study. After the application of a $0-0.6 \mathrm{M}$ linear $\mathrm{NaCl}$ gradient in the same buffer, three protein fractions were separated, and these fractions were called $\mathrm{F}_{2}, \mathrm{~F}_{3}$ and $\mathrm{F}_{4}$, according to their separation and elution order. The recovery of these fractions in terms of protein level was $4.0,0.8$ and $1.1 \%$, respectively. However, only the $\mathrm{F}_{4}$ fraction showed $\beta$-glucosidase activity, with a recovery of $26.3 \%$ of the activity. In the ion-exchange chromatography separation process, the $\mathrm{F}_{1}$ fraction showed a low specific activity, while the $\mathrm{F}_{4}$ fraction showed a high specific activity of 20.0 and a purification factor of 23 compared with the crude extract (Table 1 and Fig. 1). Therefore, the $F_{4}$ fraction was used for further purification.

Using the same extraction, fractioning and ion-exchange chromatography conditions, Matsuura and Obata (1993) partially purified $\beta$-glucosidase from soy grains. In their chromatography study, three fractions with $\beta$-glucosidase activity were separated (A, B and C). Compared with the crude extract, they observed enzyme recoveries from the A, B and $\mathrm{C}$ fractions of $4.0,6.0$ and $22.0 \%$, respectively. After the application of a $\mathrm{NaCl}$ gradient, fractions $\mathrm{B}$ and $\mathrm{C}$ showed purification factors of 8.5 and 44 , respectively. In the present study, only two fractions had $\beta$-glucosidase activity; this difference from the separation performed by Matsuura and

TABLE 1. PURIFICATION STAGES OF $\beta$-GLUCOSIDASE FROM SOY COTYLEDONS

\begin{tabular}{|c|c|c|c|c|c|}
\hline Purification stage & Protein (mg) & $\begin{array}{l}\text { Activity* } \\
\text { (U) }\end{array}$ & $\begin{array}{l}\text { Recovery } \\
(\%)\end{array}$ & $\begin{array}{l}\text { Specific } \\
\text { activity }+\end{array}$ & $\begin{array}{l}\text { Purification } \\
\text { factor }\end{array}$ \\
\hline Raw extract & $2,782.6$ & 4.81 & 100.0 & 0.0017 & 1.0 \\
\hline \multicolumn{6}{|c|}{ Precipitation $\left(\mathrm{NH}_{4}\right)_{2} \mathrm{SO}_{4}$} \\
\hline$P_{(40-85)}$ & 684.8 & 2.74 & 57.0 & 0.0040 & 2.4 \\
\hline \multicolumn{6}{|l|}{ CM-Sephadex C50 } \\
\hline $\mathrm{F}_{1}$ & 55.1 & 0.085 & 1.8 & 0.0015 & 0.9 \\
\hline $\mathrm{F}_{2}$ & 112.1 & 0.0 & 0.0 & 0.0000 & 0.0 \\
\hline $\mathrm{F}_{3}$ & 22.4 & 0.0 & 0.0 & 0.0000 & 0.0 \\
\hline $\mathrm{F}_{4}$ & 31.6 & 1.27 & 26.4 & 0.0402 & 23.6 \\
\hline \multicolumn{6}{|c|}{ Sephadex G-100 - $F_{4}$ fraction } \\
\hline $\mathrm{F}_{41}$ & 0.9 & 0.0 & 0.0 & 0.0000 & 0.0 \\
\hline $\mathrm{F}_{42}$ & 2.7 & 0.51 & 10.6 & 0.1900 & 111.8 \\
\hline $\mathrm{F}_{43}$ & 10.8 & 0.043 & 0.9 & 0.0040 & 2.4 \\
\hline
\end{tabular}

\footnotetext{
* $U=\mu \mathrm{mol} p$-nitrophenol/min.
}

$\dagger \mathrm{U} / \mathrm{mg}$ protein. 


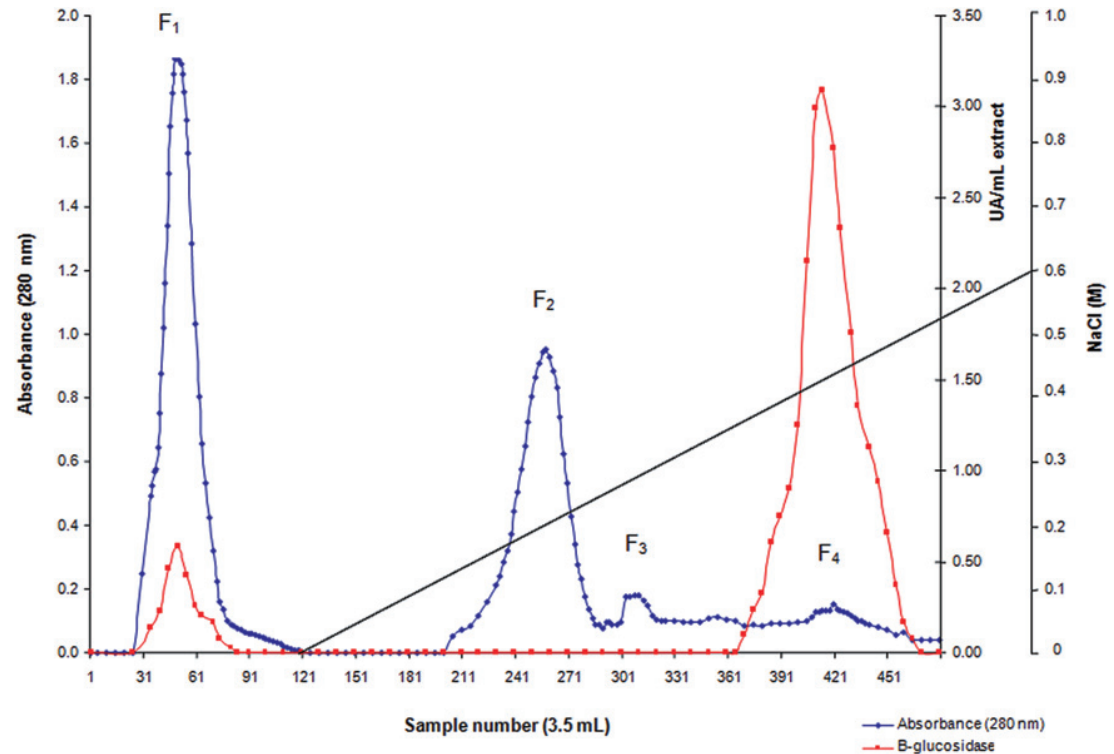

FIG. 1. CM-SEPHADEX C-50 ION-EXCHANGE CHROMATOGRAPHY OF ELUTED FRACTION $P_{40-85}$ WITH A LINEAR GRADIENT OF 0-600 mM NaCl IN 50 mM CITRATE PHOSPHATE BUFFER, pH 5.0, AND A FLOW RATE OF $27 \mathrm{~mL} / \mathrm{h}$
Obata (1993) may have been due to the characteristics of the crude extract, the initial treatment parameters or the different substrates used to determine $\beta$-glucosidase activity.

The $\mathrm{F}_{4}$ fraction applied to the Sephadex G-100 gel filtration column separated into three protein fractions called $F_{41}, F_{42}$ and $\mathrm{F}_{43}$ (Fig. 2), according to their separation and elution order. The $\mathrm{F}_{42}$ and $\mathrm{F}_{43}$ fractions showed $\beta$-glucosidase activity with a recovery of 10.6 and $0.9 \%$, respectively. Furthermore, the purification factor of the $\mathrm{F}_{42}$ fraction was 111.8 compared with the crude extract (Table 1), indicating possible enzyme purification. The separation profile and the number of frac- tions with $\beta$-glucosidase activity in the present study differed from that of Matsuura and Obata (1993) and from Hsieh and Graham (2001). Matsuura and Obata (1993) applied the B and $\mathrm{C}$ fractions independently to columns containing Sephadex G-150. After elution, they obtained partial purification of the $\mathrm{B}$ and $\mathrm{C}$ fractions. They obtained a recovery of $\beta$-glucosidase activity of $2.0 \%$ for the $\mathrm{B}$ fraction and $7.0 \%$ for the $\mathrm{C}$ fraction. Their purification factor was 87.5 for the $\mathrm{B}$ fraction and 95.9 for the $\mathrm{C}$ fraction compared with the crude extract. Hsieh and Graham (2001) partially purified $\beta$-glucosidase from germinated soy root extracts using anion-

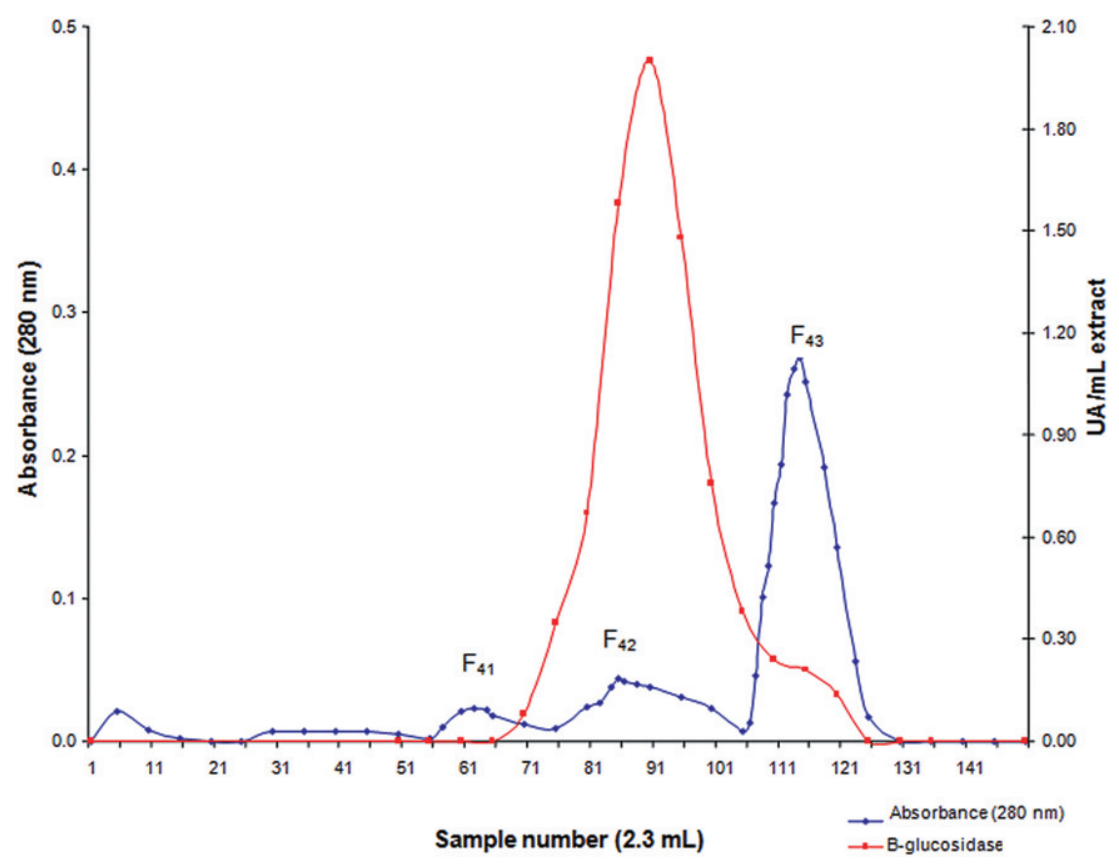

FIG. 2. SEPHADEX G100 GEL FILTRATION CHROMATOGRAPHY OF THE F FLUTED FRACTION IN 100 MM CITRATE PHOSPHATE BUFFER, pH 5.0, WITH A 17 mL/h FLOW RATE 
a

FIG. 3. (a) PROTEIN AT DIFFERENT STAGES OF PURIFICATION. LANE 1: CRUDE EXTRACT $(20 \mu \mathrm{g})$. LANE 2: FRACTION P40-85 $(20 \mu \mathrm{g})$. LANE 3: FRACTION F4 $(30 \mu \mathrm{g})$. LANE 4: FRACTION F42 $(30 \mu \mathrm{g})$. (b) SODIUM DODECYL SULFATE-POLYACRYLAMIDE GEL ELECTROPHORESIS OF $\beta$-GLUCOSIDASE F42 PURIFIED FROM SOY COTYLEDONS

(A) Molecular mass standards. (B) Purified $\beta$-glucosidase $\mathrm{F}_{42}(40 \mu \mathrm{g})$.

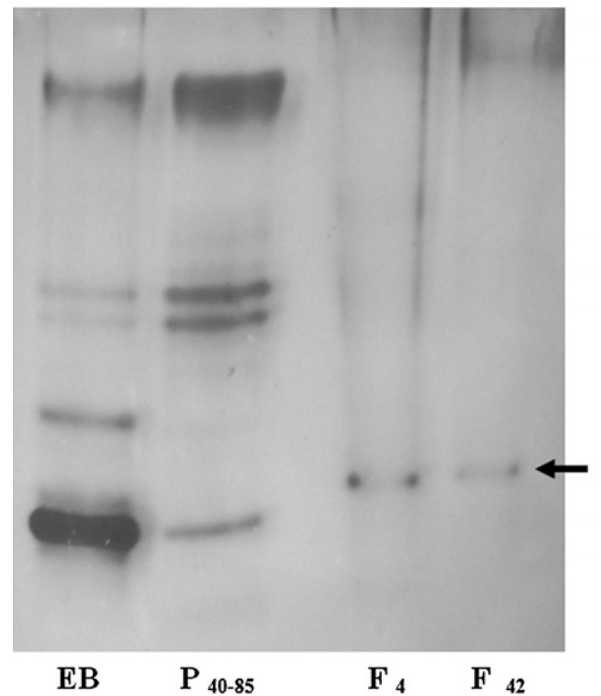

b

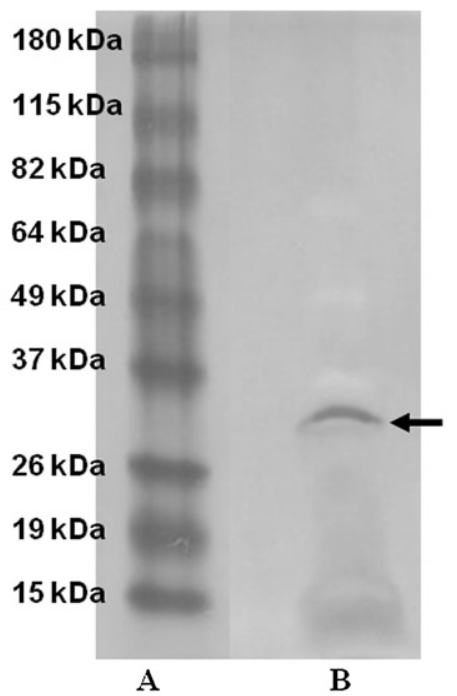

exchange chromatography in DEAE-Sephadex and cation exchange in CM-Sephadex of extracts fractionated with ammonium sulfate at $40-60 \%$ saturation. They obtained only a partially purified fraction with high specific activity that had a recovery of $20 \%$ of the activity and a purification factor of 20 compared with the crude extract. The percentage of recovery and purification factor obtained for the $\beta$-glucosidase $F_{42}$ can be compared with the values observed for this enzyme extracted from microbial sources with recovery of 4.5-37.8\% and purification factor of 10.2-176.9 (Riou et al. 1998; TraonMasson and Pellerin 1998; Zanoelo et al.2004; Nakkharat and Haltrich 2006; Kaur et al. 2007).

The different stages of purification of $\beta$-glucosidase were followed by electrophoresis in native-PAGE. It was applied to 20-30 $\mu \mathrm{g}$ of protein and separation of protein fractions was observed. The purified enzyme $\left(\mathrm{F}_{42}\right)$ migrated as a single band, demonstrating that the process of purification of this enzyme was effective (Fig. 3a).

\section{Biochemical Characterization of Purified $\beta$-Glucosidase $\mathbf{F}_{42}$}

Molecular Mass Estimate. The molecular mass of native purified $\beta$-glucosidase $F_{42}$ was estimated using Sephadex G-100 gel filtration with known molecular mass standards (Fig. 4). From the obtained linear equation $\left(y=-1.0951 x+3.4535-R^{2}=0.9703\right)$, the molecular mass of native $\beta$-glucosidase $\mathrm{F}_{42}$ was estimated to be $53 \mathrm{kDa}$. The molecular mass estimated via SDS-PAGE revealed only one protein band with a relative mobility corresponding to a molecular mass of approximately $33 \mathrm{kDa}$ (Fig. 3b), indicating that the enzyme was pure and was a dimer. These results are similar to those published by Matsuura and Obata (1993), who estimated the molecular mass of native $\beta$-glucosidase using gel filtration to be $52 \mathrm{kDa}$. However, Matsuura et al. (1995) used gel filtration/HPLC and SDS-PAGE to obtain molecular masses for $\beta$-glucosidase of 81 and $36 \mathrm{kDa}$, respectively.

The molecular mass of native $\beta$-glucosidase $\mathrm{F}_{42}$ from soy cotyledons is similar to that of $\beta$-glucosidase obtained from corn (Esen 1992; Han and Chen 2008), rice (Akiyama et al. 1998) and orange bagasse (Cameron et al. 2001). However, other vegetable $\beta$-glucosidases show a higher molecular mass and are composed of different numbers of subunits. For example, soy root $\beta$-glucosidase has two subunits of 80 and $75 \mathrm{kDa}$ (Hsieh and Graham 2001) or $58 \mathrm{kDa}$ (Suzuki et al. $2006)$, rye $\beta$-glucosidase is an oligomer containing five $60 \mathrm{kDa}$ subunits (Sue et al. 2000), and $\beta$-glucosidase from vanilla is composed of four $50 \mathrm{kDa}$ subunits (Odoux et al. 2003). According to Hsieh and Graham (2001), many $\beta$-glucosidases contain identical or nonidentical subunits, and the number of subunits may vary from 2 to 10 . Family 1 $\beta$-glucosidases have a very similar tertiary structure that tends to form homo- and hetero-oligomers. The quaternary structures of family 1 proteins show a number of oligomeric forms, including dimers, tetramers, octamers and large aggregate compounds formed by different numbers of subunits (Kim and Kim 2004).

Identification of Monosaccharides. HPAEC-PAD chromatography was used to evaluate the neutral monosaccharides in hydrolyzed $\beta$-glucosidase $\mathrm{F}_{42}$. This detected components with retention times corresponding to fucose, galactose, glucose and mannose standards. The same technique was used for the amino monosaccharides. The detection of components with retention times corresponding to 


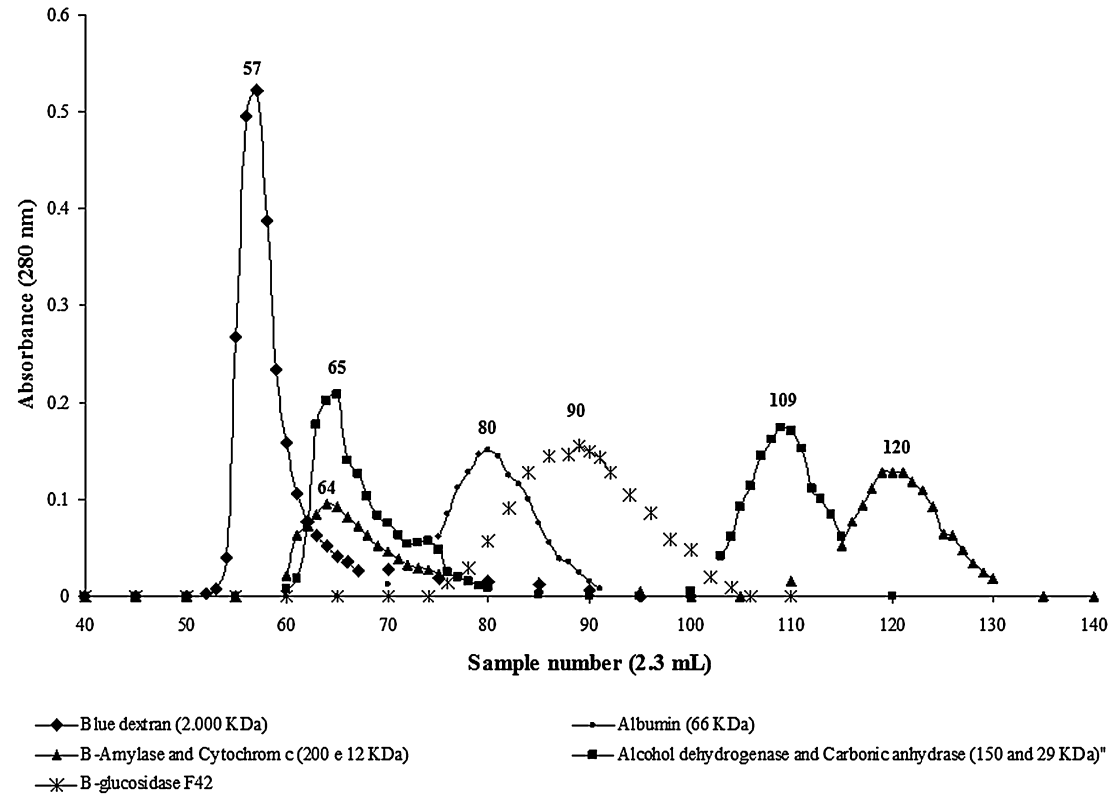

FIG. 4. MOLECULAR MASS OF NATIVE PURIFIED $\beta$-GLUCOSIDASE F 42 ESTIMATED USING SEPHADEX G-100 GEL FILTRATION ELUTED IN 100 mM CITRATE PHOSPHATE BUFFER, pH 5.0, WITH A 17 mL/h FLOW RATE galactosamine and glucosamine indicated that the purified $\beta$-glucosidase $\mathrm{F}_{42}$ is a glycoprotein, as fucose and glucosamine monosaccharides are commonly found in $\mathrm{N}$ - or O-linked glycoproteins (Montreuil et al. 1994).

\section{Effects of Temperature, pH and p-NPG Concentration on $\beta$-Glucosidase $F_{42}$ Activity}

The optimal temperature for enzyme activity was $45 \mathrm{C}$, and under such conditions, $\beta$-glucosidase $\mathrm{F}_{42}$ had an optimal $\mathrm{pH}$ of $4.5-5.5$ (Fig. 5). The enzyme activity was reduced by $71 \%$ at $\mathrm{pH} 3.5$ and $\mathrm{pH}$ 7.0. The optimal temperature of $45 \mathrm{C}$ for soy cotyledon $\beta$-glucosidase is similar to that obtained in soy by Matsuura and Obata (1993) and by Cameron et al. (2001) in Citrus sinensis var. Valencia fruit (40-45C). Other $\beta$-glucosidase sources have distinct optimal temperatures, such as 25-30C in rye (Sue et al.2000), 40C in the vanilla bean (Odoux et al. 2003), 50C in corn (Esen 1992) and 60C in barley (Leah et al. 1995). The optimal pH range of 4.5-5.5 for soy cotyledon $\beta$-glucosidase $F_{42}$ activity is similar to that described by Matsuura and Obata (1993) in soy, Akiyama et al. (1998) in rice and Leah et al. (1995) in barley. However, in corn, the optimal pH of this enzyme is higher, at 5.8 (Esen 1992).

The effect of $p$-NPG concentration on $\beta$-glucosidase activity was investigated. An increase in activity was observed up to $1 \mathrm{mM}$ of $p$-NPG, and that activity was then maintained up to $20 \mathrm{mM}$ of $p$-NPG, with no indication of inhibition or reduction in activity (Fig. 6). The $K_{\mathrm{m}}$ at $\mathrm{pH} 5.0$ and $45 \mathrm{C}$ was $0.12 \mathrm{mM}$, indicating high reaction specificity for $p$-NPG. Hsieh and Graham (2001) observed a $K_{\mathrm{m}}$ of $1.3 \mathrm{mM}$ for soy root $\beta$-glucosidase at $40 \mathrm{C}$. In the vanilla bean (Odoux et al.
2003) and Citrus sinensis var. Valencia (Cameron et al. 2001), the $K_{\mathrm{m}}$ values for $p$-NPG were reportedly $1.1 \mathrm{mM}$ (40C, $\mathrm{pH} 7.0$ ) and $0.12 \mathrm{mM}$ (40C, pH 5.0), respectively.

The $\beta$-glucosidase enzyme was stable at $25 \mathrm{C}$ for up to 4 days, with a $35 \%$ reduction in activity observed after 10 days. After $1 \mathrm{~h}$ of incubation period at 45C, the enzyme activity decreased by $60 \%$. Thus, it appears that the enzyme is not
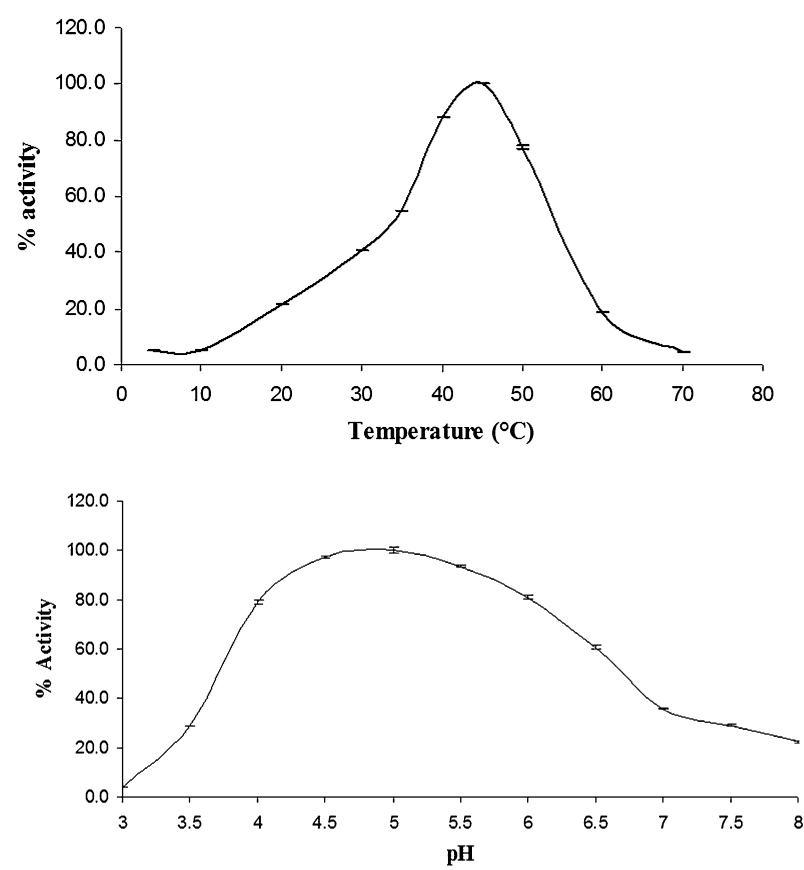

FIG. 5. EFFECTS OF TEMPERATURE AND pH ON THE ACTIVITY OF $\beta$-GLUCOSIDASE F42 PURIFIED FROM SOY COTYLEDONS 
FIG. 6. EFFECT OF $p$-NITROPHENYL$\beta$-D-GLUCOPYRANOSIDE ( $p$-NPG) CONCENTRATION ON THE ACTIVITY OF $\beta$-GLUCOSIDASE F 42 PURIFIED FROM SOY COTYLEDONS

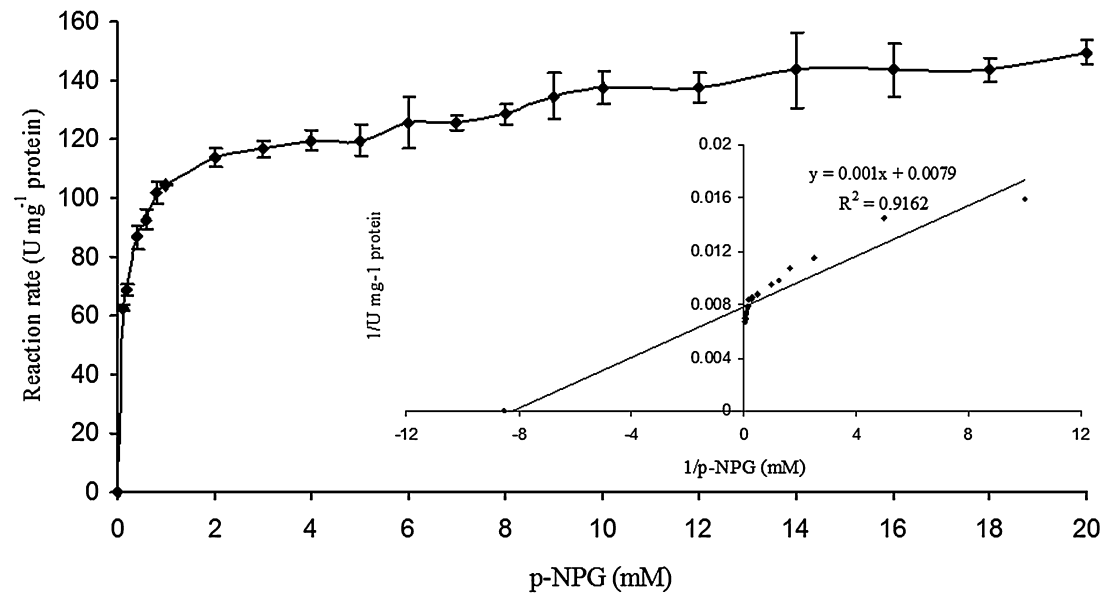

stable for long periods at its optimal temperature. After 20 min of incubation at 50C, the enzyme activity was reduced by $91 \%$. After $5 \mathrm{~min}$ of incubation at a temperature higher than 60C, the enzyme activity was reduced by $95 \%$ (Fig. 7). After four successive freeze-thaw cycles, the $\beta$-glucosidase activity remained stable.

\section{$\beta$-Glucosidase $\mathbf{F}_{\mathbf{4}}$ Substrate Specificity}

Regarding the specificity of $\beta$-glucosidase $\mathrm{F}_{42}$ for different substrates, $p$-NPG showed the highest specificity compared with other tested substrates, followed by cellobiose and gentiobiose (Table 2). The high specificity of vegetable $\beta$-glucosidase for $p$-NPG has also been observed in ripe cherries and in corn (Esen 1992; Gerardi et al. 2001). $\beta$-Glucosidase $\mathrm{F}_{42}$ showed a low specificity for daidzin and genistin. However, Matsuura and Obata (1993) observed that the daidzin and genistin extracted from soy were better substrates than other natural glucosides, such as amygdalin and esculin. It is possible that differences in the sample origins may explain the differences in the observed results.

The action of the enzyme on $p$-NPG indicates a high specificity for $\beta$-D-glucose. However, the enzyme also showed specificity for $\mathrm{D}$-mannose ( $p$-nitrophenyl- $\beta$-Dmannopyranoside) and $\mathrm{D}$-galactose ( $p$-nitrophenyl- $\beta$ - $\mathrm{D}$ galactopyranoside) (Table 3 ). Therefore, $\beta$-glucosidase may also be considered a $\beta$-D-glycosidase (Odoux et al. 2003). However, when the same substrate is switched from a para to an ortho bond position, the enzyme relative activity is reduced, indicating greater specificity of activity for the para bond position.

The bond position between two glucoses may also affect the enzyme activity. However, $\beta$-glucosidase $\mathrm{F}_{42}$ hydrolyzed
FIG. 7. EFFECT OF INCUBATION TIME AND TEMPERATURE ON THE SOY COTYLEDONS PURIFIED $\beta$-GLUCOSIDASE $F_{42}$

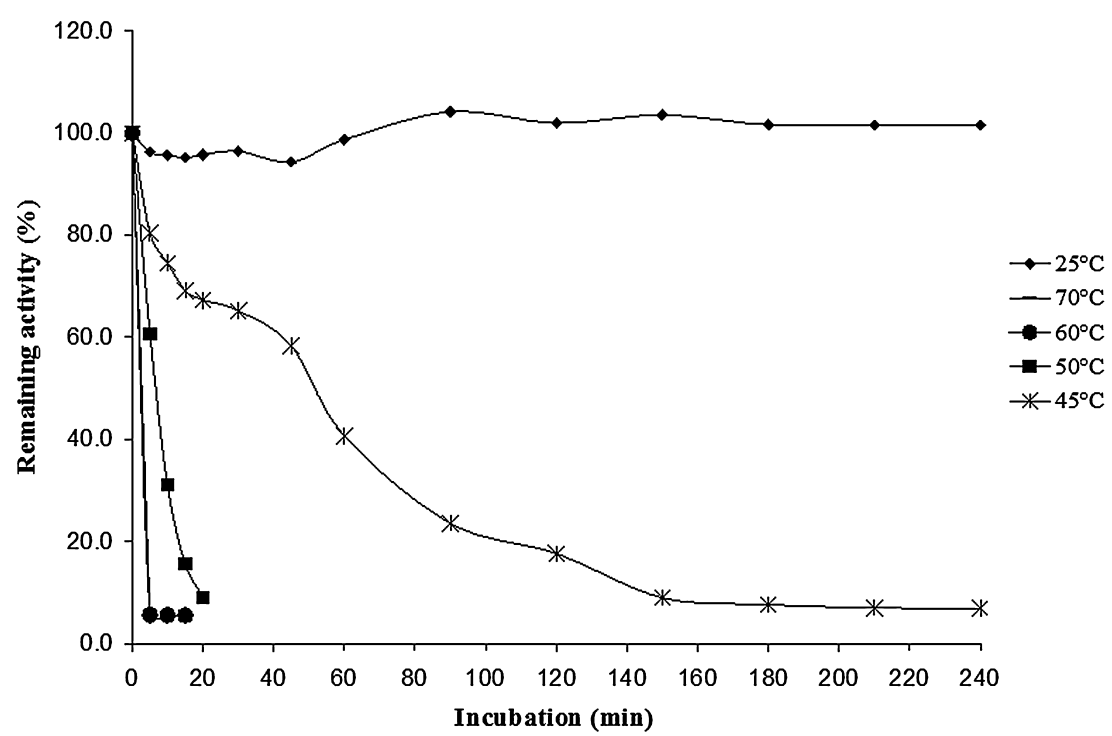


TABLE 2. SPECIFICITY OF $\beta$-GLUCOSIDASE F F2 FOR $\beta$-D-GLUCOSIDE SUBSTRATES

\begin{tabular}{ll}
\hline Substrate (1 mM) & Relative activity* (\%) \\
\hline p-Nitrophenyl- $\beta$-D-glucopyranoside & 100 \\
Cellobiose & 46 \\
Gentiobiose & 44 \\
Daidzin & 25 \\
Genistin & 24 \\
Amygdalin & 20 \\
Esculin & 17 \\
Salicin & 11 \\
Methyl- $\beta$-D-glucopyranoside & 8
\end{tabular}

* Expressed as a percentage of activity compared with the activity with $p$-nitrophenyl- $\beta$-D-glucopyranoside as a substrate.

both cellobiose $(1 \rightarrow 4)$ and gentiobiose $(1 \rightarrow 6)$ (Table 2$)$. A similar result was observed in Citrus sinensis var. Valencia (Cameron et al. 2001). However, Matsuura and Obata (1993) used purified soy enzyme and did not observe activity for

TABLE 3. SPECIFICITY OF $\beta$-GLUCOSIDASE F42 FOR DIFFERENT PARAOR ORTHO-NITROPHENYL GLUCOSIDE SUBSTRATES

\begin{tabular}{ll}
\hline Substrate (1 mM) & Relative activity* (\%) \\
\hline p-Nitrophenyl- $\beta$-D-glucopyranoside & 100.0 \\
p-Nitrophenyl- $\beta$-D-mannopyranoside & 99.3 \\
p-Nitrophenyl- $\alpha$-D-galactopyranoside & 88.7 \\
o-Nitrophenyl- $\beta$-D-glucopyranoside & 25.9 \\
p-Nitrophenyl- $\alpha$-D-mannopyranoside & $\mathrm{ND}$ \\
\hline
\end{tabular}

* Expressed as a percentage of activity compared with the activity with $p$-nitrophenyl- $\beta$-D-glucopyranoside as a substrate. $N D$, not detected. these substrates, indicating that $\beta$-glucosidase $\mathrm{F}_{42}$ is unique in its specificity for some substrates.

\section{Effects of Metallic lons and Organic Compounds on $\beta$-Glucosidase $\mathbf{F}_{42}$ Activity}

$\beta$-Glucosidase $\mathrm{F}_{42}$ activity was strongly inhibited by $1 \mathrm{mM}$ $\mathrm{HgCl}_{2}$ and $10 \mathrm{mM} \mathrm{CoCl}_{2}$ (84 and 75\%, respectively). In the presence of $10 \mathrm{mM} \mathrm{CuSO}_{4}, 1 \mathrm{mM} \mathrm{AgNO}_{3}$ or $1 \mathrm{mM} \mathrm{ZnSO}_{4}$, an inhibitory effect of greater than $50 \%$ was observed (Table 4 ). The inhibition by $\mathrm{Ag}^{+}$and $\mathrm{Hg}^{2+}$ suggests that the sulfhydryllic group may have an essential role in $\beta$-glucosidase activity (Hsieh and Graham 2001). The inhibitory effect of $\mathrm{Ag}^{+}$and $\mathrm{Hg}^{2+}$ ions at low concentrations may be explained by the fact that they interact with cysteine residues, forming an insoluble complex with sulfur, whereas the other ions form soluble complexes (Esen 1992). According to Yang et al. (2004), cysteine residues are involved in enzyme stability and activity. Thus, inhibition by these metals may be prevented in the presence of $\beta$-mercaptoethanol (Hsieh and Graham 2001).

$\mathrm{MnCl}_{2}$ at concentrations of $1 \mathrm{mM}$ and $10 \mathrm{mM}$ increased $\beta$-glucosidase activity by 10 and $63 \%$, respectively (Table 4 ). $\mathrm{Mn}^{2+}$ may be a positive modulator connected to the active site of $\beta$-glucosidase. According to Esen (2003), the presence of $\mathrm{Mn}^{2+}$ in the crystal structure of myrosinase ( $\beta$-s-glucosidase) suggests that this divalent cation may be necessary for enzyme activity. The lack of inhibition of $\beta$-glucosidase by $\mathrm{Ca}^{2+}$ is notable, as this enzyme may be used in lactose hydrolysis, decreasing the effects of this sugar in lactose-intolerant individuals (Pessela et al. 2003).

Among the organic compounds, glucono- $\delta$-lactone was a strong inhibitor of $\beta$-glucosidase, inhibiting $94 \%$ of the enzyme activity at a concentration of $10 \mathrm{mM}$. Glucono- $\delta$ -

\begin{tabular}{|c|c|c|c|c|c|}
\hline \multicolumn{2}{|c|}{ Metallic ion (mM) } & \multirow{2}{*}{$\begin{array}{l}\begin{array}{l}\text { Relative } \\
\text { activity }(\%)^{*}\end{array} \\
16\end{array}$} & \multicolumn{2}{|c|}{ Organic compound (mM) } & \multirow{2}{*}{$\begin{array}{l}\text { Relative } \\
\text { activity (\%)* } \\
38\end{array}$} \\
\hline $\mathrm{HgCl}_{2}$ & 1 & & Glucono- $\delta$-lactone & 1 & \\
\hline & 10 & n.d. & & 10 & 6 \\
\hline \multirow[t]{2}{*}{$\mathrm{AgNO}_{3}$} & 1 & 47 & PMSF & 1 & 78 \\
\hline & 10 & n.d. & & 10 & 64 \\
\hline \multirow[t]{2}{*}{$\mathrm{ZnSO}_{4}$} & 1 & 44 & EDTA & 1 & 79 \\
\hline & 10 & 86 & & 10 & 77 \\
\hline \multirow[t]{2}{*}{$\mathrm{CuSO}_{4}$} & 1 & 86 & & & \\
\hline & 10 & 36 & & & \\
\hline \multirow[t]{2}{*}{$\mathrm{CoCl}_{2}$} & 1 & 90 & & & \\
\hline & 10 & 25 & & & \\
\hline \multirow[t]{2}{*}{$\mathrm{CaCl}_{2}$} & 1 & 96 & & & \\
\hline & 10 & 96 & & & \\
\hline \multirow[t]{2}{*}{$\mathrm{MnCl}_{2}$} & 1 & 110 & & & \\
\hline & 10 & 163 & & & \\
\hline
\end{tabular}

TABLE 4. EFFECTS OF METALLIC IONS AND ORGANIC COMPOUNDS ON $\beta$-GLUCOSIDASE $\mathrm{F}_{42}$ ACTIVITY

\footnotetext{
* Expressed as a percentage of activity compared with the activity with $p$-nitrophenyl- $\beta$-Dglucopyranoside as a substrate.

EDTA, ethylenediaminetetraacetic acid; n.d., not determined; PMSF, phenylmethylsulfonyl fluoride (in $95 \%$ ethanol).
} 
lactone has been described as a strong inhibitor of $\beta$-glucosidase from different vegetable sources (Matsuura and Obata 1993; Cameron et al. 2001; Hsieh and Graham 2001). PMSF and EDTA had moderate effects on the enzyme, inhibiting only about $20 \%$ of its activity. The lack of inhibition by EDTA indicates that the enzyme does not require a metal cofactor in its active site. However, the low level of inhibition may be related to a possible change in amino acid load at the active site caused by this organic compound (Harnpicharnchai et al. 2009). The lack of inhibition by PMSF, which interacts with histidine and serine residues in the active site, indicates that these amino acids do not have an essential role in $\beta$-glucosidase activity (Wolosowska and Synowiecki 2004).

Glucose has an inhibitory effect on $\beta$-glucosidase $\mathrm{F}_{42}$ activity, acting as a competitive inhibitor. Dixon's (1953) report established a $K_{\mathrm{i}}$ of $2 \mathrm{mM}$. According to Yang et al. (2004), competitive inhibition from glucose is a common characteristic of $\beta$-glucosidases vegetable and microbial. Cameron et al.(2001) and Han and Chen (2008) reported inhibition of $\beta$ glucosidase by glucose in orange bagasse and corn forage, respectively. However, vanilla $\beta$-glucosidase is not inhibited by glucose at concentrations lower than $2 \mathrm{M}$ (Odoux et al. 2003).

\section{ACKNOWLEDGMENTS}

The authors would like to thank the Secretaria de Estado da Ciência, Tecnologia e Ensino Superior-Fundo Paraná Fundação Araucária for financial resources and the Coordenação de Aperfeiçoamento de Pessoal de Nível Superior - CAPES for scholarships.

\section{REFERENCES}

AGUIAR, C.L. and PARK, Y.K. 2004. Conversão de daidzina e genistina de soja por beta-glicosidase de Aspergillus oryzae. B.CEPPA. 22, 183-195.

AKIYAMA, T., KAKU, H. and SHIBUYA, N. 1998. A cell wall-bound beta-glucosidase from germinated rice: Purification and properties. Phytochemistry 48, 49-54.

ARAÚJO, J.M.A., CARLOS, J.C.S. and SEDYAMA, C.S. 1997. Isoflavonas em grãos de soja: importância da atividade de beta-glucosidase na formação do sabor amargo e adstringente. Cienc. Tecnol. Aliment. 17(2), 137-141.

BERHOW, M.A. 2002. Modern analytical techniques for flavonoid determination. In Flavonoids in the Living Cell, Vol. 505 (B.S. Buslig and J.A.E. Manthey, eds.) pp. 61-76, Kluwer Academic/Plenum Publishers, New York, NY.

BHATIA, Y., MISHRA, S. and BISARIA, V.S. 2002. Microbial beta-glucosidase: Cloning, properties, and applications. Crit. Rev. Biotechnol. 22, 375-407.

BROUNS, F. 2002. Soya isoflavones: A new and promising ingredient for the health food sector. Food Res. Intern. 35, 187-193.
CAMERON, R.G., MANTHEY, J.A., BAKER, R.A. and GROHMANN, K. 2001. Purification and characterization of a beta-glucosidase from Citrus sinensis var. Valencia fruit tissue. J. Agric. Food Chem. 49, 4457-4462.

CHIOU, T.Y., LIN, Y.H., SU, N.W. and LEE, M.H. 2010. Beta-glucosidase isolated from soybean okara shows specifity toward glucosyl isoflavones. J. Agric. Food Chem. 58, 8872-8878.

CHUN, J., KIM, J.H. and KIM, J.H. 2008. Enrichment of isoflavone aglycones in soymilk by fermentation with single and mixed cultures of Streptococcus infantarius 12 and Weissella sp.4. Food Chem. 109(2), 278-284.

CORRADI DA SILVA, M.L., IZELI, N.L., MARTINEZ, P.F., SILVA, I.R., CONSTANTINO, C.J.L., CARDOSO, M.L., BARBOSA, A.M., DEKKER, R.F.H. and SILVA, G.V.J. 2005. Purification and structural characterization of $(1 \rightarrow 3 ; 1 \rightarrow 6)-\beta$-D-glucans (botryosphaerans) from Botryosphaeria rhodina grown on sucrose and fructose as carbon sources: A comparative study. Carbohydr. Polym. 61, 10-17.

DAVIS, B.J. 1964. Disc electrophoresis. II. Method and application to human serum proteins. Ann. N. Y. Acad. Sci. 121, 404427.

DIXON, M. 1953. The determination of enzyme inhibitor constants. Biochem. J. 55, 170-171.

ELIFIO, S.L., SILVA, M.L.C.C., IACOMINI, M. and GORIN, P.A.J. 2000. A lectin from the lichenized Basidiomycete Dictyonema glabratum. New Phytol. 148, 327-334.

ESEN, A. 1992. Purification and partial characterization of maize (Zea mays L.) $\beta$-glucosidase. Plant Physiol. 98, 174-182.

ESEN, A. 2003. $\beta$-Glucosidase. In Handbook of Food Enzymology (J.R. Whitaker, A.G.J. Voragem and D.W.S. Wong, eds.) pp. 774-786, Marcel Dekker, New York, NY.

FAURE, D. 2002. The family-3 glycoside hydrolases: From housekeeping functions to host-microbe interactions. Appl. Environ. Microbiol. 68(4), 1485-1490.

GERARDI, C., BLANDO, F., SANTINO, A. and ZACHEO, G. 2001. Purification and characterization of a $\beta$-glucosidase abundantly expressed in ripe sweet cherry (Prunus avium L.) fruit. Plant Sci. 160, 795-805.

HAN, Y. and CHEN, H. 2008. Characterization of $\beta$-glucosidase from corn stover and its application in simultaneous saccharification and fermentation. Bioresour. Technol. 99, 6081-6087.

HARNPICHARNCHAI, P., CHAMPREDA, V., SORNLAKE, W. and EURWILAICHITR, L. 2009. A thermotolerant $\beta$-glucosidase isolated from an endophytic fungi, Periconia sp., with a possible use for biomass conversion to sugars. Protein Expr. Purif. 67, 61-69.

HSIEH, M.C. and GRAHAM, T.L. 2001. Partial purification and characterization of a soybean beta-glucosidase with high specific activity towards isoflavone conjugates. Phytochemistry 58, 995-1005.

ISMAIL, B. and HAYES, K. 2005. $\beta$-Glycosidase activity toward different glycosidic forms of isoflavones. J. Agric. Food Chem. $53,4918-4924$. 
IZUMI, T., PISKULA, M.K., OSAWA, S., OBATA, A., TOBE, K., SAITO, M., KATAOKA, S., KUBOTA, Y. and KIKUCHI, M. 2000. Soy isoflavone aglycones are absorbed faster and in higher amounts than their glucosides in humans. J. Nutr. 130, 1695-1699.

KAUR, J., CHADHA, B.S., KUMAR, B.A., KAUR, G.S. and SAINI, H.S. 2007. Purification and characterization of $\beta$-glucosidase from Melanocarpus sp. MTCC 3922. Electron. J. Biotechnol. 10(2), 260-270.

KIM, S. and KIM, I. 2004. Oligomeric structure of $\beta$-glucosidases. J. Photosci. 11, 121-127.

LAEMMLI, U.K. 1970. Cleavage of structural proteins during the assembly of the head of the bacteriophage $\mathrm{T}_{4}$. Nature 227 , 680-685.

LAI, H. and YEN, G. 2002. Inhibitory effect of isoflavones on peroxynitrite-mediated low-density lipoprotein oxidation. Biosci. Biotechnol. Biochem. 66(1), 22-28.

LEAH, R., KIGEL, J., SVENDSEN, I. and MUNDY, J. 1995. Biochemical and molecular characterization of a barley seed $\beta$-glucosidase. J. Biol. Chem. 270(26), 15789-15797.

LIU, Z., KANJO, Y. and MIZUTANI, S. 2010. A review of phytoestrogens: Their occurrence and fate in the environment. Water Res. 44, 567-577.

LOWRY, O.H., ROSENBROUGH, N.J., FARR, A.L. and RANDAL, R.J. 1951. Protein measurement with the folin phenol reagent. J. Biol. Chem. 193, 265-275.

MA, W., YUAN, L., YU, H., DING, B., XI, Y., FENG, J. and XIAO, R. 2010. Genistein as a neuroprotective antioxidant attenuates redox imbalance induced by $\beta$-amyloid peptides $25-35$ in PC12 cells. Int. J. Dev. Neurosci. 28, 289-295.

MATSUDA, M., MIYAZAKI, T., MATSUMOTO, Y., OHBA, R., TERAMOTO, Y., OHTA, N. and UEDA, S. 1992. Hydrolysis of isoflavones in soybean cooked syrup by Lactobacillus casei subsp. rhamnous IFO 3425. J. Ferment. Bioeng. 74(5), 301-304.

MATSUURA, M. and OBATA, A. 1993. $\beta$-glucosidases from soybeans hydrolyze daidzin and genistin. J. Food Sci. 58, 144-147.

MATSUURA, M., SASAKI, J. and MURAO, S. 1995. Studies on beta-glucosidase from soybeans that hydrolyze daidzin and genistin: Isolation and characterization of an isozyme. Biosci. Biotechnol. Biochem. 59(9), 1623-1627.

MONTREUIL, J., BOUQUELET, S., DEBRAY, H., LEMOINE, J., MICHALSKI, J.-C., SPIK, G. and STRECKER, G. 1994. Glicoproteins. In Carbohydrate Analysis: A Practical Approach, 2nd Ed., (M.F. Chaplin and J.F. Kennedy, eds.) pp. 181-229, Oxford University, Oxford, $\mathrm{OH}$.

MORANT, A.V., JORGENSEN, K., JORGENSEN, C., PAQUETTE, S.M., SÁNCHES-PEREZ, R., MOLLER, B.L. and BAK, S. 2008. $\beta$-Glucosidases as detonators of plant chemical defense. Phytochemistry 69, 1795-1813.

NAKKHARAT, P. and HALTRICH, D. 2006. Purification and characterization of an intracellular enzyme with $\beta$-glucosidase and $\beta$-galactosidase activity from the thermophilic fungus Talaromyces thermophilus CBS 236.58. J. Biotechnol. 123, 304-313.
NIELSEN, B.L. and BROWN, L.R. 1984. The basis for colored silver-protein complex formation in stained polyacrylamide gels. Anal. Biochem. 141(2), 311-315.

ODOUX, E., CHAUWIN, A. and BRILLOUET, J. 2003. Purification and characterization of vanilla bean (Vanilla planifolia Andrews) $\beta$-D-glucosidase. J. Agric. Food Chem. 51, 3168-3173.

OTIENO, D.O. and SHAH, N.P. 2007. Endogenous $\beta$-glucosidase and $\beta$-galactosidase activities from selected probiotic micro-organisms and their role in isoflavone biotransformation in soymilk. J. Appl. Microbiol. 103(4), 910-917.

PESSELA, B.C.C., MATEO, C., FUENTES, M., VIAN, A., GARCIA, J.L., CARRASCOSA, A.V., GUISÁN, J.M. and FERNÁNDEZ-LAFUENTE, R. 2003. The immobilization of a thermophilic $\beta$-galactosidase on Sepabeads supports decreases product inhibition. Complete hydrolysis of lactose in dairy products. Enzyme Microb. Technol. 33, 199-205.

RIOU, C., SALMON, J.M., VALLIER, M.J., GÜNATA, Z. and BARRE, P. 1998. Purification, characterization, and substrate specificity of a novel highly glucose-tolerant $\beta$-glucosidase from Aspergillus oryzae. Appl. Environ. Microbiol. 64, 3607-3614.

SANTOSH, T.R., BALASUBRAMANIAN, K.K. and LALITHA, K. 1999. Enhancement of beta-glucosidase and beta-galactosidase of Trigonella foenum-graecum by exposure to the allelochemical mimosine. J. Agric. Food Chem. 47, 462-467.

SUE, M., ISHIHARA, A. and IWAMURA, H. 2000. Purification and characterization of a $\beta$-glucosidase from rye (Secale cereale L.) seedlings. Plant Sci. 155, 67-74.

SUZUKI, H., TAKAHASHI, S., WATANABE, R., FUKUSHIMA, Y., FUJITA, N., NOGUCHI, A., YOKOYAMA, R., NICHITANI, K., NISHINO, T. and NAKAYAMA, T. 2006. An isoflavone conjugate-hydrolyzing $\beta$-glucosidase from the roots of soybean (Glycine max) seedlings. J. Biol. Chem. 281(40), 30251-30259.

TRAON-MASSON, M.P. and PELLERIN, P. 1998. Purification and characterization of two $\beta$-d-glucosidases from an Aspergillus niger enzyme preparation: Affinity and specificity toward glucosylated compounds characteristics of the processing of fruits. Enzyme Microb. Technol. 22, 374-382.

WOLOSOWSKA, S. and SYNOWIECKI, J. 2004. Thermostable $\beta$-glucosidase with a broad substrate specifity suitable for processing of lactose-containing products. Food Chem. 85, 181-187.

YANG, L., NING, Z.S., SHI, C.Z., CHANG, Z.Y. and HUAN, L. 2004. Purification and characterization of an isoflavone-conjugates-hydrolyzing $\beta$-glucosidase from endophytic bacterium. J. Agric. Food Chem. 52, 1940-1944.

ZANOELO, F.F., POLIZELI, M.L.T., TERENZI, H.F. and JORGE, J.A. 2004. $\beta$-glucosidase activity from the thermophilic fungus Scytalidium thermophylum is stimulated by glucose and xylose. FEMS Microbiol. Lett. 240, 137-143. 